\title{
AIDS-Related Diffuse Large Cell Lymphoma
}

National Cancer Institute

\section{Source}

National Cancer Institute. AIDS-Related Diffuse Large Cell Lymphoma. NCI Thesaurus.

Code C7213.

A diffuse large cell lymphoma developing in an HIV positive patient. 